Available Online at https://journal.unismuh.ac.id/index.php/otoritas

Otoritas : Jurnal Ilmu Pemerintahan, 10 (2), October 2020, 142-164

\title{
Migrant Labour Recruitment Reform in Malaysia: Towards Ethical and Zero-Cost Migration
}

\author{
Choo Chin, Low*) \\ History Section, School of Distance Education, Universiti Sains Malaysia, \\ Gelugor, 11800, Penang, Malaysia.
}

Received: 12 December 2019; Revised: 4 August 2020; Accepted: 15 September 2020

\begin{abstract}
The pressures exerted by migrant workers' countries of origin, regional calls for migrant protection, and global initiatives have pushed the Malaysian government for labour reforms in line with International Labour Organization standards. A weak labour migration mechanism has led to human trafficking, debt bondage, and workers' exploitation. Since 2018, Malaysia has concluded and renegotiated improved memoranda of understanding (MoUs) with countries of origin to address forced labour and human-trafficking. Reforming the recruitment system is formalised through government-to -government agreements to eliminate agents, enhance ethical recruitment, and adopt a zero migration-cost model. The analysis shows that the newly negotiated MoUs are significant in tackling the issue of irregular migration in three aspects, by including a clause on repatriation, changing to the government recruitment model, and adopting the employer-pays model. This research utilises official documents, media statements, and secondary literature.
\end{abstract}

Keywords: ASEAN; Ethical Recruitment; Forced Labour; Irregular Migration; MoU; Repatriation

How to Cite: Low, C. C. (2020). Migrant Labour Recruitment Reform in Malaysia: Towards Ethical and Zero-Cost Migration. Otoritas : Jurnal Ilmu Pemerintahan, 10(2), 142-164.

Permalink/DOI: https://doi.org/10.26618/ojip.v10i2.4641

${ }^{*}$ Corresponding Author.

E-Mail : lowc@usm.my

Copyright (C) 2020, Otoritas : Jurnal Ilmu Pemerintahan, ISSN: 2088-3706 (Print), ISSN: 2502-9320 (Online) 
Available Online at https://journal.unismuh.ac.id/index.php/otoritas

Otoritas : Jurnal Ilmu Pemerintahan, 10 (2), October 2020, 143

\section{INTRODUCTION}

In August 2018, the Malaysian Government declared a moratorium on all bilateral memoranda of understanding (MoUs) while seeking to renegotiate the terms, as part of its efforts against human trafficking and forced labour. Through bilateral MoUs with countries of origin, Malaysia sought to enhance ethical recruitment standards (ILO, 2018). Malaysia's first initiative towards ethical recruitment was implemented through the Nepal-Malaysia MoU signed in 2018, which stipulated that employers would bear all the recruitment costs. The agreement, at the Nepalese government's initiative, was a milestone for protecting the rights of Nepali migrant workers. They could work in Malaysia at zero cost, because their Malaysian employers would bear all costs, including the repatriation cost. The Malaysian government reiterated its commitment to follow the principles of the ILO convention by providing basic facilities to Nepali workers (Poudal, 2018). It was an example of a government-to-government (G2G) recruitment plan that aimed to eliminate private recruiters while curbing human trafficking and exploitation of workers. The high recruitment costs borne by migrant workers under private recruitment processes had led to incidents of modern-day slavery known as debt bondage. Nepal, Indonesia, and Bangladesh are the top three source countries for the approximately two million registered foreign workers in Malaysia (Malaysia targets middlemen, 2018).

The move towards zero-cost and employer-pays recruitment approaches demonstrated the government's commitment to ethical recruitment, replacing the previous business model. Ethical recruitment necessarily eliminates the intermediaries and middlemen who charged hidden costs incurred in the migrant recruitment process. Forced labour and debt bondage are the result of unethical recruitment (Hall, 2019). Unethical recruitment and worker exploitation have been the major reasons underlying the suspension of the supply of foreign workers by the source countries. In 2018, Nepal temporarily banned the sending of its workers due to the exorbitant fees charged by private companies appointed by the Malaysian government (Perumal, 2018). In 2018, Indonesia considered a ban on its citizens working as maids in Malaysia, following the death of an Indonesian domestic worker, until the employment process is restructured. Migrant rights' groups, netizens, lawmakers, and activists called for a stricter legal framework to protect the welfare of migrant workers. Since the expiration of the MoU between the two countries in 2016, there has been no cooperation between them (Malaysia's meeting with Indonesia, 2018).

Meanwhile, in January 2020, Cambodia urged Malaysia to expedite the signing of an MoU on anti-human trafficking to protect Cambodian workers, especially domestic helpers. Cambodia is reluctant to send its domestic workers to Malaysia until the agreement is signed, despite the fact that Cambodia's Labour Ministry had lifted the moratorium on Cambodian maids. In January 2018, after several bilateral talks with Malaysia on welfare and legal protection (Cambodia urges Malaysia, 2020; David, 2020), Cambodia announced the lifting of its ban on sending maids to Malaysia. As for the BangladeshMalaysia foreign-worker crisis, Malaysia froze the recruitment of Bangladeshi workers in 2018 due to the broken recruitment processes of private agencies. The Bangladeshi government refused to send its citizens until a low-cost and transparent recruitment system is implemented. Malaysia urged Bangladesh to better manage the unchecked sending of its workers. Both countries acknowledged that the high cost is caused by the existence of illegal brokers in both countries. 
The Ministry of Human Resources (MOHR) was concerned about possible sanctions imposed, as Malaysia had been placed on the Tier 2 Watch List of the US State Department's Trafficking in Persons (TIP) report for 2018 and 2019 consecutively. In order to prevent labour abuse by employers and exploitation by agents, Malaysia is working closely with the countries of origin to implement "zero cost for the workers" (Thomas, 2020).

This positive development is prompted by both internal and external factors. Internally, the labour reform took place under the new Pakatan Harapan (PH) government that took over the administration beginning in May 2018. The MOHR initiated a series of reforms with the appointment of an "Independent Committee on the Management of Foreign Workers," in August 2018, to streamline the policies and management of foreign workers. Malaysia renegotiated its MoUs with Nepal, Indonesia, Bangladesh, and India, which would expire soon. The main obstacle was ensuring migrant workers' protection, especially for domestic helpers (Mohd Arop, 2018). Countries of origin, such as Indonesia, Nepal, Cambodia, and Bangladesh, have played an active role in safeguarding the welfare and safety of their migrant workers, as discussed below.

Reforming the labour migration system goes in tandem with regional and international efforts towards migrant protection. Regional commitment to labour migration is promoted through the ASEAN Consensus on the Protection and Promotion of the Rights of Migrant Workers, signed on November 14, 2017, by the leaders of the Association of Southeast Asian Nations (ASEAN). Regional instruments such as the ASEAN Consensus play a limited role, as they are non-binding and do not carry legal weight (Rother, 2018; Thuzar, 2018). The Malaysian government is facing international pressure to address human trafficking and migrant exploitation following the observations in the US State Department's TIP Report. The country could face international sanctions prohibiting foreign countries from investing in Malaysia if its status drops to Tier 3. Malaysia was downgraded to the Tier 2 watchlist in 2018, similar to the same position it occupied in 2015 and 2016 (Govt working on improved, standardised MOU, 2018).

Under pressure from the migrants' countries of origin, possible international trade sanctions, regional commitment, and civil society movements, Malaysia has rewritten the terms of its MoUs in line with International Labour Organization (ILO) standards. Based on the 2018 model agreement with Nepal, Malaysia negotiated improved and standardised MoUs with other countries of origins. The standardised MoUs are significant in tackling the issue of irregular migration in these three aspects: First, they include a clause on repatriation, addressing the problem of migrants who overstay at the end of their employment contracts. Second, they are based on the G2G recruitment model to tackle human trafficking and workers' exploitation. Third, the cost of recruitment is to be covered by the hiring companies rather than the foreign workers, known as zero migration cost (Govt working on improved, standardised MOU, 2018; Mandal, 2018; Poudal, 2018). These developments can be interpreted as enhancing the capacity of legal migration to ensure workers are safely deployed to Malaysia.

This article examines the development of migrant labour recruitment reforms in Malaysia, looking at how Malaysia has resorted to bilateral MoUs to resolve the issue of irregular migration. The first section evaluates the role of regional migration governance of labour mobility. This is followed by an analysis of the new elements introduced by the MoUs signed by Malaysia with labour-sending states, namely the implementation of G2G recruitment, the transfer of recruitment 
costs to employers, and the inclusion of repatriation clauses. Finally, it reviews the effects of such reforms on Malaysia's migration governance. The findings show that bilateralism is a more effective mode of regulating irregular labour migration into Malaysia caused by limited regional migration governance, and of addressing recruitment, mobility, and repatriation of migrant labours.

\section{RESEARCH METHODS}

This research is based on the Malaysian case study, as the country has initiated major labour reforms since 2018 towards the elimination of outsourcing companies, ensuring zero migration costs and ethical recruitment. These belated reforms are a milestone in the labour migration history of Malaysia, after having regulated labour migration for more than three decades, since 1984. The developments are significant as they address labour relations with sending countries and adhere to ILO labour standards, at a time when regionalism of migration is emerging in Southeast Asia with the region embracing migration-related declarations and initiatives. This paper draws upon document analysis of migration-related declarations of ASEAN, official reports of international migrant associations, secondary literature, press releases, and the press statements of civil society actors and migrant associations, as well as online newspapers.

\section{LITERATURE REVIEW}

In Southeast Asia, labour mobility has been addressed exclusively from economic, trade, and security perspectives. When the ASEAN was established in 1967, its charter did not consider the movement of labour. Since the economic liberalization through the ASEAN Free Trade Area (1992), labour migration has been approached in isolation from economic integration. The migration subject has not been considered because coun- tries of origin and of destination have conflicting interests. Countries of destination want to maintain their control over their national migration policies, which have security implications, while countries of origin desire more protective measures for their citizens working overseas and some form of integration. A regional framework for migration could properly address irregular migration (Battistella, 2002).

Scholars suggest that the low-skilled labour migration framework is absent in the regional migration governance. Regional instruments, such as the ASEAN Agreement on the Movement of Natural Persons (MNP) and the ASEAN Economic Community (AEC), mainly focused on the governance of the movement of skilled workers and they consider questions of regional migration as part of economic integration efforts (Lavenex et al., 2016; Ramji-Nogales, 2017). The MNP (2012) facilitates the mobility of skilled labourers and professionals for the purposes of investment and business, in accordance with the 1995 ASEAN Framework Agreement on Services (Lavenex et al., 2016). The MNP aims to create an effective mechanism to further liberalize and facilitate the movement of natural persons toward the free flow of skilled labour in the ASEAN and to eliminate practically all restrictions in the temporary cross-border movement of the natural persons involved in the provision of trade and investment. At the same time, it protects the integrity of member states' borders and their domestic labour force (Article 1, MNP) (ASEAN, 2012). It would not affect natural persons seeking access to permanent employment or to citizenship and residence (Article 2, MNP) (ASEAN, 2012).

Similarly, the establishment of the AEC in 2015 has also provided for the free flow of skilled labour migrants (as well as goods, investment, and capital), but it does not address the movements of low- 
skilled workers (Ramji-Nogales, 2017). The AEC is a major milestone in the regional economic integration agenda in ASEAN. According to the new AEC Blueprint 2025 adopted by ASEAN leaders in 2015, it is envisaged that the 10 ASEAN member states are economically, sustainably and gainfully integrated in the global economy (AEC, 2015). The governance of unskilled labour migration in Southeast Asia is much needed because the migratory flow within the region mainly comprises unskilled and semi-skilled workers, with irregular migrants facing the risk of exploitation and trafficking (Kneebone, 2010; Orbeta \& Gonzales, 2013).

Moreover, the regional migration cooperation is framed from the security perspective. The ASEAN members have developed a regional perspective on irregular migration rooted in security concerns through the Manila Process (initiated in 1996, which is no longer active), the Bangkok Declaration (1999), the ARIAT Meeting held in Manila (2000), and the Bali Process (2002) (Battistella, 2002). The Bali Process initially had a limited focus on security aspects related to people smuggling and trafficking. Since 2011, its scope has widened to reduce irregular migration, with the 2011 agreement to establish a Regional Cooperation Framework (RCF) (Lavenex et al., 2016). To facilitate the RCF's implementation, a Regional Support Office (RSO) of the Bali Process was established in 2012 to reduce irregular migration in the AsiaPacific region. As an inclusive and nonbinding initiative of the Bali Process, the RCF seeks to address the root causes of irregular movement, promote legal migration, avoid creating pull factors within the region, create disincentives for irregular movement (such as readmission agreements), promote human life and dignity, build the capacity to process mixed migration flows, promote information exchange, and share collective responsibility while respecting the sovereignty of the concerned states (Regional Support Office of the Bali Process, 2012a).

While a regional perspective has been adopted to solve economic and security problems in the ASEAN, migrant labour management has been dealt with through bilateralism. Regionalism is important for better regularisation of migration management among the countries of origin, transit, and destination. The issue of migration is a regional issue. Regionalising the issue is important as migration is not merely a bilateral issue (Orbeta \& Gonzales, 2013; Ramasamy, 2004). Bilateralism had been the principal mode of migration cooperation within ASEAN. The Asian experience has shown that multilateral and regional governance are important for supporting bilateral agreements. Wickramasekera (2015) states, "Bilateral arrangements are accorded increasing legitimacy and have greater potential for impact when they are concluded in the context of regional and multilateral frameworks, which help to reduce unequal power relations between origin and destination" (Wickramasekera, 2015). According to Kneebone (2010), the greatest limitation in the regional migration governance is that "labor migration is perceived as a national issue that concerns state sovereignty" rather than as a transnational issue. In contrast, securityrelated issues, such as trafficking, have been viewed as regional issues with collaborative frameworks (Kneebone, 2010).

There are two main challenges in the regional efforts on irregular migration. The main challenge is that irregular migration is treated separately from regular migration. The Bangkok Declaration on Irregular Migration (1999) called upon the signatory countries to facilitate the regular movement of labour in order to reduce irregular migration (Article 3) (ASEAN, 1999). Governing regular migration within the ASEAN is of fundamental in addressing irregular migration. The Kuala Lumpur Declaration on Irregular 
Movement of Persons in Southeast Asia (2015) acknowledged that that the irregular movement of persons could contribute to other forms of transnational crime in addition of human trafficking and migrant smuggling (ASEAN, 2015). Researchers have called for the integration of labour migration into regional development efforts and greater cooperation at the regional levels to reduce irregular migration (Martin \& Abella, 2014). The ASEAN initiatives toward closer economic integration only address the movement of skilled workers. The mobility flow of lowskilled migrant workers has yet to be addressed collectively in the region. More challenges have been encountered since the relaxing of regional borders restrictions, following the establishment of the ASEAN Community in 2015 (DGICM, 2014).

The second challenge is the lack of a regional mechanism for handling the repatriation of irregular migrants. No effective bilateral or regional frameworks specify the conditions under which undocumented workers would be repatriated. As noted by Nesadurai (2013) "There is no dearth of bilateral or ASEAN agreements on migrant workers; these, however, focus more on ensuring a steady supply of migrant workers, rather than on how migrant workers should be treated during their employment or when detained and deported" (Nesadurai, 2013). The Bangkok Declaration on Irregular Migration called on the obligation of the country of origin to accept its nationals back and the obligation of the countries of transit and destination to provide protection and assistance where appropriate (Article 12). Similarly, the RSO of the Bali Process outlined voluntary repatriationcapacity building and support as one of its projects to reduce irregular movement in the region (Regional Support Office of the Bali Process, 2012b).

Though the ASEAN members have pledged enhanced cooperation in facilitat- ing the re-admission of deportees, the process has only made headway in Malaysia since 2014 after years of diplomatic setbacks between Malaysia and the sending states. Prior to the existence of bilateral cooperation, undocumented immigrants had been deported without the sending countries' full cooperation, causing diplomatic setbacks. The countries of origin have been reluctant to take back their nationals and share the cost of repatriation despite the initial collaborations established with Indonesia, the Philippines, Thailand, and Myanmar (Low \& Mokhtar, 2017). The unilateral enforcement of Malaysia's immigration law weakened the effectiveness of its repatriation process. A World Bank report (2015) suggests that "Malaysia's repatriation policies is not well balanced between stakeholders" (World Bank, 2015). The report stated that countries of origin could play a more active role in deportation and Malaysia should strengthen the bilateral MoUs' clauses on returning home. Compliance with deportation could be made a factor for the assessment of the MoUs (World Bank, 2015).

At the bilateral level, Malaysia is relying on MoUs to prevent workers' exploitation by illegal brokers, labour recruitment companies and human traffickers. As part of the national efforts to combat forced labour and human trafficking, Malaysia regulates the recruitment of migrant workers through bilateral MoUs with their countries of origin. These new MoUs establish a mechanism of recruitment based on G2G procedures, without agents, middlemen, and private employment agencies in either country. Instead, recruitment is to be implemented through government departments (ILO, 2018). This paper extends the literature to examine how Malaysia has addressed the issue of irregular migration through bilateral efforts. These changes aim to prevent forced labour and human trafficking while ensuring that ethical recruitment is in 
Available Online at https://journal.unismuh.ac.id/index.php/otoritas

Otoritas : Jurnal Ilmu Pemerintahan, 10 (2), October 2020, 148

place.

\section{RESULTS AND DISCUSSION}

Eliminating Intermediaries through G2G Recruitment

In the labour migration history of Malaysia, there have been several foreign worker crises that resulted in diplomatic tensions in which the countries of origin placed moratoriums on the placement of their workers. The Philippines and Indonesia (in 2009), followed by Cambodia (in 2011) stopped sending their workers to Malaysia due to widespread abuse; the moratorium remained in effect until a new MoU was approved that enhanced the rights and protection of the workers. An inherent limitation of the existing bilateral MoUs is that they are nonstandardised for different countries of origin, resulting in diversification in the recruitment process (ILO, 2016, p. 14). The Malaysian economy is highly dependent on foreign labour. Foreign workers' share of the Malaysian labour force has increased from 1.683 million (14.1\%) in 2010 to 2.235 million (15.5\%) in 2017. They mainly occupied low-skilled jobs, contrasting with locals, who held the semi -skilled and skilled jobs. In 2017, foreign workers constituted $51 \%$ of low-skilled jobs, $17.3 \%$ of semi-skilled jobs, and $2.7 \%$ of skilled jobs, in the total employment statistics of the country (Khazanah Research Institute, 2018). As of August 31, 2019, there were 1.99 million foreign workers in Malaysia. The manufacturing sector employed 706,502 workers, followed by construction $(429,552)$, plantations $(268,203)$, agricultural $(150,003)$, and 130,450 domestic maids (Tay, 2019). Since 1984, Malaysia has regulated the recruitment of foreign workers through bilateral MoUs with fifteen source countries; Indonesia, Thailand, Vietnam, Cambodia, Philippines, Laos, Nepal, Sri Lanka, India, Bangladesh, China, Pakistan, Uzbekistan, Turkmenistan, and Kazakhstan
(World Bank, 2013).

These MoUs failed to ensure ethical recruitment and to regulate the migration costs borne by the foreign workers. Despite the bilateral MoUs outlining the recruitment costs, the real costs were much higher, because migrants were charged hidden fees by third-party intermediaries, depending on the employment sector and the country of origin. The high migration cost was caused by the business-tobusiness (B2B) recruitment mechanism in which private agencies worked with recruiting agents and their sub-agents in the source country. This encouraged foreign workers to enter the country illegally to avoid the cost or to overstay their employment contracts to pay off their debt. The whole recruitment industry "generates gains that mostly favour thirdparty intermediaries" (World Bank, 2015).

The foreign-worker recruitment process was lengthy and complicated, with many parties involved at various points along the chain. At the bottom of the chain, foreign workers were paying a huge amount of money to the sub-agents in their home country, to the international recruitment agents in Malaysia, and to Malaysian employment agents. The hiring of foreign workers is a lucrative industry due to the outsourcing of functions to private agencies and the unregulated activities of these agents (Lee \& Idrus, 2018). An ILO report titled "Situation and gap analysis on Malaysian legislation, policies and programmes, and the ILO Forced Labour Convention and Protocol" revealed that migrant workers were vulnerable to various forced-labour practices, including fraudulent recruitment, deception about the type of employment, breaches of contract, payment of excessive recruitment fees, reduction or non-payment of salaries, retention of passports by employers, excessive working hours, and conditions leading to debt bondage, under the existing recruitment system (Lee \& Idrus, 


\section{8).}

The 2012 Malaysia-Bangladesh MoU is an example of a G2G attempt to eliminate private recruiters. Under the $\mathrm{G} 2 \mathrm{G}$ agreement, recruitment and deployment were handled by the Bangladesh Bureau of Manpower, Employment, and Training (Migrant Forum in Asia, 2017). The agreement set the minimum monthly wage at MYR 900, introduced an online application system, and fixed recruitment fees at Tk 40,000 (US\$ 520). It targeted the recruitment of 30,000 Bangladeshis in the plantation sector with standard employment contracts and reduced the recruitment fees borne by Bangladeshi workers to discourage the practice of overstaying their contracts to pay off their debts (ILO, 2016).

The activities of private recruiters under private management to procure Bangladeshi workers in 2007-2008 resulted in an overflow of Bangladeshi workers, some sent by non-existing private companies. Many of them who did not secure a job and were left stranded slept at the Bangladesh High Commission in Kuala Lumpur, many of whom had to return home. In 2007, Malaysia banned recruitment of workers from Bangladesh until the new MoU based on the G2G model was signed in 2012, aiming to eliminate agents' involvement. It successfully reduced the migration cost from Tk 1.6 lakh, under the B2B system, to $\mathrm{Tk} 40,000$ to work in Malaysia (Palma, 2015). However, the G2G model was strongly protested by private agencies in both countries and the employing companies, who preferred the B2B. Private agents lost their livelihoods while Malaysian employers had to bear the cost of levy, previously borne by workers. As a result of powerful lobbying from the private agents, the G2G labour recruitment system failed; only 10,000 workers were recruited under the system (Palma, 2015; Tusher, 2016).

In 2016, Bangladesh and Malaysia initiated the G2G-Plus modality under which private firms were allowed to send workers to Malaysia, with a target of recruiting 1.5 million Bangladeshi workers, men and women, for the plantation, service, manufacturing, and construction sectors, with three-year contracts. Employers were responsible for the repatriation cost of each worker, capped at MYR 1,985 maximum, in addition to workers' security deposits, levies, visa fees, and health and compensation insurance (Carvalho, 2016). However, the G2G-Plus agreement failed to provide a low-cost and transparent system of recruitment. Under the G2G -Plus operation between 2016 and 2018, workers were charged excessively-Tk 4 lakh (MYR 19,000). The system was not transparent, as there were only ten Bangladeshi companies allowed to recruit Bangladeshi workers, resulting in the monopolisation of the foreign-worker industry. Again in September 2018, Malaysia suspended the recruitment of Bangladeshi workers (Recruitment in Malaysia, 2020). The suspension applied as well to the online platform, the Foreign Worker Application System (SPPA), which only allowed 10 appointed agencies to recruit. The Bangladeshi Expatriates' Welfare and Overseas Employment Minister insisted that Bangladesh would not allow the cost of migration to increase; thus, the two countries began negotiations on a new recruitment mechanism (Voon, 2019).

Malaysia confronted another foreign worker crisis with Nepal. In May 2018, the new Nepalese government barred its citizens from working in Malaysia due to its restrictive immigration requirements. The recruitment process was complex, with migrant workers having to go through various immigration requirements (i.e., security, health checks, immigration clearance) conducted by different private companies, as part of the visa requirements. The complex mechanism created many layers of intermediaries, each layer having its own costs. Nepal questioned whether the involvement of pri- 
vate companies was necessary, urging the Malaysian government to reduce the visa costs, which amounted to 19,000 Nepali rupees (MYR 700), and demanded a simple, transparent, and cost effective recruitment process (Nepal ready to negotiate MOU, 2018).

More specifically, Nepal protested against the virtual monopoly of the recruitment process, in the hands of a private company appointed by Malaysia to handle the medical screening process, to the exclusion of other companies. The new Nepalese government, which took over the administration in February 2018, took a firm position against Malaysia's recruitment policy, which required migrant workers to go through a single agency (Bestinet, Sdn. Bhd.) designated by the Malaysian government to carry out pre-departure biomedical screening. There were only 37 medical centres in Nepal accredited by Malaysia to ensure that medical screening was performed according to Malaysian requirements and its results properly integrated and uploaded to the system. Apart from the MYR 100 medical fees charged by Bestinet, there were additional fees collected by other providers for Immigration Security Clearance (ISC), Visa Luar Negara (VLN), and the services of the One Stop Centre (OSC) (Perumal, 2018).

The Malaysian government was criticised for outsourcing the duties of the Immigration Department to private agencies. Work-visa processing was outsourced to a private company (Ultra Kirana, Sdn. Bhd.), and passport processing was outsourced to One Stop Centre (OSC), both of which chose a Kathmandu-based partner, VLN Nepal, to perform the task. Biometric health screening was outsourced to Bestinet Sdn. Bhd., who partnered with the Nepal Health Professional Federation to carry out biometric screening through its 37 medical centres. Previously, workers could process visas through any agency and obtain medical tests from 200 government-approved health facilities. Newspapers in Nepal reported that private companies worked together with Nepali and Malaysian businessmen and bureaucrats to profit from Nepali workers. Nepal's Labour Minister, Gokarna Bista, responded by cracking down on several Kathmandu-based companies accused of cheating the workers. In 2018, there were 400,000 Nepalis in Malaysia (Sapkota \& Alhadjri, 2018).

Labour relations between the two countries underwent a crisis when Nepal's Ministry of Labour, Employment and Social Security filed court cases against the Nepal Health Professional Federation and all the biomedical centres for cheating Nepali workers. The Kathmandu District Court cleared Bestinet from the charges on December 31, 2018. Directors of VLN/OSC were also sued for charging additional fees, and the District Court of Lalitpur cleared them of the charges. The Nepalese Government appealed to the High Court and lost. The High Court of Patan, in its judgment of January 29, 2019, declared Bestinet and VLN/OSC as legal, thereby declaring their shutdown by the Ministry of Labour as unlawful. The ministry was admonished, as the ban on Nepali workers to Malaysia resulted in the loss of 150 billion rupees' remittance from Malaysia (Nepal courts cleared Malaysian firms, 2019).

During discussions at a bilateral Joint Working Committee, the major debate was regarding Nepal's demand to decentralise the medical screening institutions from the 37 recognised medical centres to 122 new testing centres throughout Nepal. Nepal's Ministry of Labour, Employment and Social Security hoped to ensure a level playing field for all private agencies and ensure transparency, while making it more convenient for the workers. Another major concern expressed in the talks, as part of Nepal's migration governance reform, was to reduce the undue burden on migrant workers. It 
was unreasonable for workers to put in eight months of a two-year contract just to cover the migration costs incurred. Moreover, Malaysia's agreements with labour-supplying countries are nonstandardised, in terms of migration cost. For example, foreign workers from Indonesia and Bangladesh do not pay the cost, while Nepali workers were paying various fees to the middlemen in both countries, causing them to be unfairly penalised. Both countries agreed that it was unfair for Nepali workers to pay these costs (Dixit, 2019).

Malaysia's Ministry of Human Resources (MOHR) agreed, in the talks between Nepal and Malaysia, to direct recruitment based on G2G without intermediaries. Eliminating intermediaries would end the corruption and private companies' monopoly of security and medical check-ups. The new PH government acknowledged that the involvement of third-party companies appointed by the previous Barisan National (BN) government had created many problems (Best to Revert to Old System, 2018). New terms of agreement were now possible, as both countries had undergone changes of government. The Malaysian Minister of Human Resources, M. Kulasegaran, was concerned about safeguarding labour rights, while Nepal's Minister for Labour, Employment and Social Security, Gokarna Bista, wanted Nepali workers "to spend less on fees, earn more and be treated well" (Dixit, 2019).

Addressing Human Trafficking and Forced Labour

On October 29, 2018, in Kathmandu, Malaysia and Nepal signed a new MoU on workers' recruitment, employment and repatriation. Two important elements were introduced -zero migration cost for Nepali workers and protection in line with ILO guidelines. The zero migrationcost model was adopted by which Nepali migrant workers do not pay any fees. Em- ployers are responsible for all expenses, including the recruitment service charges, round-trip airfare, visa fees, health checkups, security screening, levy charges, accommodations, and health and accident insurance, that had previously been borne by the workers. Malaysian employers pay a service charge to Nepali recruiters of up to half-a-month's salary and must deposit the workers' salaries through a banking channel on the seventh day of the month. Nepali migrant workers are entitled to change jobs in case of labour abuses or their employer's bankruptcy. They are allowed 15 days' paid leave if a family member dies in Nepal, and in the event of a worker's death, the employer is responsible for repatriation of their remains (Mandal, 2018; Poudal, 2018).

For the recruitment of Nepali workers, according to the MoU, fair recruitment practices have been adopted. Following the signing of the MoU, the recruitment costs, estimated between MYR 6,300 and MYR 7,900, are transferred to the Malaysian employers, who now must pay a higher cost. While they supported the move to improve ethical recruitment, as advocated under the ILO standards, they were not ready for the higher costs imposed. They urged the government to reduce their costs and to include more source countries (Rahim, 2019). Employers complained about the increase in manufacturing costs and the resulting price of goods and services, as a result of the new MoU. However, the MOHR was more concerned with the dire consequences of imposed trade sanctions. According to the US State Department's 2018 Trafficking in Persons (TIP) report, Malaysia was downgraded to Tier 2. Improving the MoUs was essential to curb human trafficking and exploitation of workers. The labour-supply MoU with Nepal has set the precedent for improved and standardised agreements with other labour-sending countries. It addresses human trafficking issues and migrant 
workers' exploitation while conforming to ILO standards. After the successful conclusion of the MoU with Nepal, Malaysia began negotiating with Bangladesh, Indonesia, and Vietnam to incorporate the ILO's standard elements, as their current MoUs were expiring soon (Babulal \& Abdul Karim, 2018).

In bilateral discussions with Bangladesh to resume the supply of foreign workers, Malaysia proposed a zero-cost recruitment model. Eliminating forced labour is central to avoid trade sanctions by the United States, in view of Malaysia's having been placed on the 2019 Tier 2 Watch List in the US State Department Trafficking in Persons (TIP) report for the second consecutive year. The Minister of Human Resources, Kulasegaran, urged Bangladesh to ensure a sound system to prevent the unchecked sending of workers through private agents. Malaysia agreed to lift the moratorium imposed in 2018 as soon as new terms could be finalised, modelled upon the Malaysia-Nepal MoU with regard to recruitment, employment, and repatriation (Malaysia looking at zero-cost system, 2020).

Globally, industries are adopting the principle of zero-cost migration. As Malaysia and Bangladesh worked on a new recruitment plan, civil society was not consulted in the process. Migrant rights non-governmental organisations (NGOs), represented by Caram Asia, Tenaganita and the North-South Initiative, called for consultation with civil society organisations (CSOs), grassroots organisations, and stakeholders of both countries in addressing any action plan. They advocated the elimination of middlemen and labour agents in both countries, identified as the root cause of labour-rights exploitation. Instead, hiring should take place through a government mechanism to manage the selection and placement of workers in order to ensure integrity in recruitment governance. Regular labour inspections can reduce forced labour and ensure com- pliance with employment contracts. In addition, a redress mechanism and a transparent regularisation system would help the victims of fraud who become undocumented. Migrant rights NGOs further called upon Bangladesh to facilitate the repatriation of its nationals by processing and granting their identification documents swiftly (Caram Asia et al., 2019).

As for Cambodia, two Memoranda of Understanding (MoUs) were signed in 2015 on recruitment of foreign and domestic workers, respectively. The MoUs ensured the systematic management of recruitment, employment, and repatriation, while protecting Cambodian workers' rights, in accordance with ILO principles. Restructuring the recruitment process was important to avoid human trafficking and forced labour (Shah, 2015). As of 2015, there were 8,000 registered Cambodian workers, including 3,000 domestic workers, in Malaysia. The two countries used MoUs to deal with labour abuse by employers, such as non-issuance of employment contracts, retaining workers' passports, and non-payment of wages. Both MoUs provided for an employment contract in the employee's native language, the settling of wages, the right to file complaints with Malaysia's Labour Department and the inclusion of repatriation mechanisms. These MoUs shared similar objectives of protecting workers' rights by requiring recruitment through licensed agencies and forbidding employers to hold workers' passports (Govt signs MoU, 2015).

In 2017, Cambodia agreed to resume the flow of Cambodian maids after a joint technical committee finalised the terms of recruitment, training, and employment conditions. A six-year ban had been imposed by Cambodia's Prime Minister Hun Sen in 2011, following widespread abuse, including overwork, salary disputes, physical abuse, and death of its domestic maids (Kannan, 2017a). Cambodia's Ministry of Labour cooperated closely with its 
Malaysian agencies to monitor the selection, training, and sending of their workers and maids to work in Malaysia. Pursuant to initiatives undertaken by Cambodia, a few migrant protection MoUs were signed. In 2017, Cambodia's Ministry of Labour and the Malaysian Association of Foreign Maid Agencies (PAPA) signed a Memorandum of Agreement (MoA) on protection and welfare of migrant domestic workers. PAPA was tasked with providing each worker a free smartphone, monitoring their salary payments, and ensuring that employment agencies had signed contracts (Shah, 2017). In order to ensure that their welfare was protected, a mechanism of workplace inspection was carried out quarterly. Workers would be provided with accident and health insurance at work (David, 2020). The MoA ensures that workers are not obligated to work in sectors other than those stipulated in the contract, and that they are covered by insurance. As a signatory to the agreement, PAPA is responsible for facilitating the entire employment process from selection, including training and relocation of Cambodian domestic workers in Malaysia (Adilah, 2017).

In addition, the recruitment agencies in Cambodia and Malaysia concluded a migrant-worker protection $\mathrm{MoU}$ to ensure the safety of Cambodian maids. The Association of Cambodian Recruitment Agencies and the Malaysia National Association of Employment Agencies signed an MoU in 2017, agreeing to work together to curb illegal trafficking and migration in the maid-trade and domestic slavery. The MoU outlined the responsibilities of Cambodian and Malaysian agencies throughout the employment process, from recruitment, training, and management to eventual repatriation (Agreement Signed to Protect Migrant Workers, 2016). The collaboration was expanded in 2018 with a new migrant-worker protection $\mathrm{MoU}$ signed by two Cambodian recruitment associations with three associations from
Malaysia. It established cooperation among the five migrant recruitment associations to protect the safety of Cambodian workers in Malaysia. The MoU served as a new mechanism to assist the Labour Ministry of Cambodia in ensuring that Cambodian migrant workers' welfare is protected through cooperation with Malaysian partners. With the signing of the MoU, Cambodia anticipated a decrease in the abuse of Cambodian workers (Kunthear, 2018).

For Indonesian domestic workers, the MoUs signed in 2006 had failed to protect their welfare. The MalaysiaIndonesia MoU signed in 2006 was criticised for allowing Malaysian employers to retain passports and not providing guidelines on minimum wages (World Bank, 2013). In June 2009, Indonesia, cognizant of the risks faced by its 230,000 maids in Malaysia, banned sending domestic workers to Malaysia, following reports of maids being abused by employers. The issue of maid abuse resulted in Indonesians demonstrating at the Malaysian Embassy's residence in Jakarta, creating tensions in bilateral relations. Malaysia's efforts in response included inspections in homes, interviews of maids and employers, and establishing a helpline (Zulfakar \& Singh, 2010).

An MoU on the Recruitment and Placement of Maids was signed with Indonesia in 2011, lifting the two-year ban on Indonesian domestic workers that had followed rights violation complaints lodged by maids that included physical abuse, non-payment of salary, and overworking-as much as 14 hours a day seven days a week (Purwaningsih, 2011). The MoU established new requirements, such as direct deposit of wages into bank accounts, passports to be retained by the workers, and one day off per week. Recruitment fees paid by the workers were fixed at MYR 1,800 with another MYR 2,711 borne by employers; standard employment contracts were obligatory, but it 
failed to establish a minimum wage (ILO, 2016). It was criticised by Migrant Care, an Indonesian NGO, who advocated that a standard minimum wage not be lower than the Malaysian standards. Though a joint task force was established to monitor the implementation of the MoU, it was doubtful that the mechanism would ensure that the terms would be implemented (Purwaningsih, 2011).

Migrant protection, especially for domestic workers, was weak. Migrant Care estimated about 120 deaths of Indonesians in Malaysia from 2016 to 2018. Human trafficking was the principal driver of domestic slavery abroad. Many were victims of human trafficking syndicates and worked in the country illegally; Indonesians seeking employment abroad were more vulnerable to human trafficking due to legal migration being costly and complex. Migrant Care called on the Indonesian Government to ensure cheaper and safer procedures for migrant workers to prevent their falling prey to trafficking syndicates. As the existing MoU between the two countries expired in 2016, the two governments began to work on a new MoU that would safeguard Indonesians abroad (Barker, 2018). In February 2018, the death of an Indonesian domestic worker in Penang prompted Indonesia to consider halting the recruitment of its domestic workers for work in Malaysia. The case stirred debates in Indonesia on the lack of protection for migrant workers abroad. From Indonesia's point of view, a moratorium would allow the country to restructure the employment system to prevent similar cases. Indonesia also considered introducing a minimum wage requirement (Indonesia mulls ban, 2018). For Malaysia, the freeze would only cause Indonesian citizens to enter illegally, as long as the demand is high. Illegal recruitment would subject workers to abuse and exploitation, paving the way to human trafficking. Malaysia urged Jakarta not to ban legal migration (Lokman \& Fong,
2018).

Tenaganita, a Malaysian-based NGO, believed that recruiting through private agencies involved excessive costs, leading potential migrants to resort to trafficking syndicates. According to statistics of the Malaysian Maid Employers' Association (MAMA), there were more than 250,000 registered domestic workers in Malaysia in 2017. One of every 20 maids ran away from their employers, largely due to abuse, poor working conditions, or a desire for freedom and better opportunities elsewhere. Tenaganita welcomed Malaysia's new efforts to introduce direct hiring of domestic helpers from nine selected countries-Indonesia, Thailand, Cambodia, the Philippines, Sri Lanka, India, Vietnam, Laos, and Myanmar. The elimination of agents is a step forward in reducing the costs (Abu Bakar, 2017).

Effective January 1, 2018, direct hiring of domestic workers was implemented through the Online Maids System (SMO). Under this system, operated by the Immigration Department, employers could hire a maid in eight days with a lower fee of MYR 1,635. Previously, employers paid between MYR 12,000 and 18,000. The SMO is an efficient and cost-effective system which eliminates intermediaries and makes it affordable for lower-income Malaysian households to hire maids. To be eligible, the maids must already be in the country with a valid or expired social visit pass. A fine of MYR 900 would be charged if employers attempt to hire maids who have overstayed their contracts. Employers must purchase medical, accident, and life insurance and have a written work contract with their employees (Kannan, 2017b).

The SMO addresses the welfare of domestic maids through a standard agreement outlining the duties and responsibilities of both employer and employee. Among other regulations, employers shall provide reasonable accommodations, basic amenities, and adequate daily 
meals; shall require the domestic worker to engage in only household duties; and shall insure the domestic worker with the Foreign Worker Compensation Scheme, with regard to medical expenses. Moreover, the SMO has a screening mechanism in place to red-flag and exclude Malaysian employers with a bad record-a criminal record, a history of bankruptcy, or of nonpayment of wages. After employers have passed the screening stage, they are assessed as to their ability to pay wages on time through bank accounts. Between January 1 and March 1, 2018, about 10,054 Malaysians signed up, and 1,616 potential foreign maids registered on the system. The Immigration Department approved the employment of 295 foreign maids during that period (Lokman \& Fong, 2018).

Another positive development aiming to tackle human trafficking was the abolishment of outsourcing companies. Outsourcing agencies were attributed with unfair treatment of workers, cases of human trafficking, and various other unfavourable complaints (Zainul, 2018). Effective March 31, 2019, the outsourcing to third parties of recruiting and managing foreign workers was terminated. The move, according to the Malaysian Employers Federation, was adopted to ensure better treatment of foreign workers. Labour contractors are profit-orientated; they strive to pay the minimum to workers while charging exaggerated fees to employers. MOHR took over the task of supplying foreign workers, which was previously outsourced by the Home Ministry to more than 100 outsourcing companies and involved 26,000 foreign workers. Outsourcing companies have to seek new employers or repatriate their outsourced foreign workers. Outsourced foreign workers not absorbed by new employers became illegal if they stayed in Malaysia after March 31, 2019 (Zainal, 2019).
Tackling Illegal Migration and Repatriation

Malaysia is resorting to bilateral MoUs as an instrument to secure the cooperation of the countries of origin in the deportation of overstaying migrants. The issues of irregular migration and foreign workers who overstay, among others, were discussed during negotiations with Bangladesh, Indonesia, and Vietnam. Prior to the signing of labour agreements, Malaysia hoped to solve the issue of illegal foreign workers, which affected Malaysia's status in the US TIP reports. The MOHR maintained that renewed MoUs must include enforcement provisions for illegal foreign workers, and that the countries of origin must commit to taking back their nationals who overstay their employment contracts and become undocumented. According to Kulasegaran, "What we are saying now is very simple - if you send workers to my country, you must send the best workers, you must send disciplined people" (Malaysia to go slow on labour MoU, 2018).

In the past, the sending states' unwillingness to cooperate in the repatriation of irregular migrants further strained bilateral ties. The intensification of raids, detention, and deportation has created interstate conflicts, especially with Indonesia. The bilateral tension with Indonesia heightened in 2002 when Malaysia carried out its national crackdown code Ops Nyah II Bersepadu and the mass deportation of irregular migrants. Indonesian officials criticised the inhumane treatment of Indonesian illegal migrants in Malaysian detention centres. The immediate deportation also created overcrowding in the Indonesian transit ports. While Malaysia complained that Indonesia had been uncooperative in assisting with the repatriation process, Indonesia deemed Malaysia inconsiderate of the pressing economic situation in Indonesia when handling deported migrants (Liow, 
2003). Similarly, the Philippines demanded a halt to Malaysia's mass deportation operations in 2002 and asked for the Philippine mission to examine the conditions of Filipino detainees in Malaysia's detention centres. In 2005, a PhilippineMalaysia Joint Commission on Sabah Repatriates was established to facilitate the repatriation of Filipino nationals back to the Philippines (Nesadurai, 2013).

The Malaysia-Indonesia deal on repatriation in 2014 stipulated that Indonesia agreed to bear the costs of its citizens' airfare and travel documents, while Malaysia dropped all charges on the irregular migrants. More importantly, Indonesia agreed to shoulder the repatriation costs, which had been a thorny issue for the Malaysian government. The first batch of 494 Indonesian deportees was released from immigration depots, its biometrics were taken, and the group was dispatched in December 2014, using five Indonesian military planes. It was the first joint immigration deal between the nations. Malaysia benefited from the agreement in terms of reducing the administrative, human resource, and financial costs of operating the detention centers (Cheng, 2014). The repatriation mission was implemented in coordination with the Indonesian embassy in Malaysia. The Indonesian military's involvement was evident in the use of its Air Force's Hercules planes to repatriate irregular Indonesian workers (Marbun, 2014). Subsequent repatriation operations in 2015 were carried out via lowcost commercial planes. As of December 9, 2015, in total, 27,000 Indonesian illegal immigrants were sent home. Those repatriated were blacklisted from entering Malaysia within a period of one to five years, depending on the offenses committed. Indonesia will undertake capacity-building programs for its citizens who have been repatriated to avoid illegal re-entry into Malaysia, following the two countries' mutual agreement to reduce the number of undocumented workers (Shahar,
2015).

Malaysia and the Philippines signed a deal on the repatriation of Filipino illegal immigrants in 2016. During Philippine President Rodrigo Duterte's visit to Kuala Lumpur, he agreed to take back in stages the 7,000 undocumented Filipinos residing illegally in Sabah, while Malaysia's former Prime Minister, Najib Razak, agreed to provide the Malaysian naval fleet to facilitate the return. The first batch of deportees to Zamboanga (Philippines) consisted of 400 Filipinos, who were detained in the Sandakan temporary detention center. The agreement was also military in nature as the Philippines agreed to open up its international waters to Malaysian and Indonesian maritime forces to hunt the ASG (Sabah deports 400 Filipino illegals, 2016).

Myanmar's cooperation in repatriating its nationals was noticeable, especially during Malaysia's national crackdown. In 2016, approximately 2,000 Myanmar migrant workers were detained across Malaysia, with over 300 having served their sentences but could not afford to return home, even after the citizenship verification process was completed. The lack of funding was critical when earlier plans to repatriate over 700 Myanmar workers had been cancelled. In July 2016, Myanmar announced another repatriation plan, with chartered flights and financial aid from private donors, such as the KBZ Brighter Future Myanmar Foundation and Myanmar Airline International, which eased the process (Nyan, 2016a). In a periodic visit to the detention camps, the Myanmar embassy officials arranged for repatriation, prioritising women, children, and elderly people (Nyan, 2016b). The Myanmar embassy in Kuala Lumpur assisted in checking the detainees' identities, leading to the swift issuance of travel documents. It privatised the repatriation by allowing two business groups to verify the citizenship of Myanmar migrants in the detention camps and to charge each 
person RM650 (US\$160) (Zaw, 2016).

The Cambodia-Malaysia collaboration in repatriation was outlined in two MoUs signed in 2015. The MoU on the Recruitment and Employment of Workers and the MoU on the Recruitment and Employment of Domestic Workers were significant to the repatriation process as both included an article on the process of repatriating workers and domestic workers (Shah, 2015).

The lack of funding of Cambodia's embassy in Kuala Lumpur was the main issue confronted in the repatriation process. Thus, NGOs paid the fines for visa overstaying, while the International Organization for Migration sponsored the Cambodian workers' flights. The number of Cambodians seeking shelter at the embassy increased, following the enforcement operation Ops Mega that started on July 1, 2017 (Peter, 2017). In addition to those evading the immigration raids, some Cambodian workers were escaping from their employers due to abuse and mistreatment. They approached the embassy to help them receive their final wages and return home. The Cambodian Embassy in Kuala Lumpur worked with Malaysian authorities in the repatriation process (Sotheary, 2017).

In the case of Bangladesh, ministerial discussions sought ways of repatriating undocumented Bangladeshi workers and overstaying workers. Strengthening labor relations was part of MalaysianBangladeshi bilateral efforts to address the issues of high recruitment fees and exploitation in the recruitment system (Malaysia wants to work with Bangladesh, 2018).

\section{CONCLUSION}

Over the past decade, Malaysia has improved its migration governance at the national and bilateral levels through the elimination of agents, private actors, and outsourcing companies rooted in the system. An institutional reform on direct government recruitment was implemented to ensure a higher standard of employment and ethical recruitment. Previous recruitment agreements based on B2B opened the way to various forms of abuse due to the active role played by private actors, misconduct by recruiting agents, failure to protect labour rights, and high migration costs borne by the migrant workers. The newly-introduced G2G recruitment, as in the case of Nepal, attempt to address the root causes of workers' vulnerability through the principles of zero migration cost and fair recruitment policies. The failed experiences of $\mathrm{G} 2 \mathrm{G}$ and G2G-Plus with Bangladesh illustrated clearly that the interests of recruitment agencies in both countries dominated over the interests of migrant workers. By renegotiating all the MoUs based on ILO standards, Malaysia has demonstrated that migrant workers are not to be treated as a commodity, and the foreign workers' industry should not be treated as a for-profit trade. Bangladesh, Indonesia, and Cambodia have yet to resume sending their migrant workers until a better migrant protection system is in place.

The adoption of zero migration costs and the employer-pays-recruitment model showed that migrant welfare is being taken seriously by the MOHR, after decades of the hard-line approach-raids, detention, and deportation of undocumented migrants. While these reforms strengthen the mechanisms of legal migration, much of their implementation will depend on the enforcement of national labour laws. Eliminating recruitment fees has only partially addressed the issue of migrant welfare; there are other aspects of irregular migration, such as systematic regularisation programmes, humane deportation, and migrant rights protection, yet to be resolved at the national level. 
Available Online at https://journal.unismuh.ac.id/index.php/otoritas

Otoritas : Jurnal Ilmu Pemerintahan, 10 (2), October 2020, 158

\section{ACKNOWLEDGEMENT}

This work was supported by Universiti Sains Malaysia (Bridging Grant: Grant number 304/PJJAUH/6316524).

\section{REFERENCES}

Abu Bakar, S. K. (2017, October 27). NGO lauds direct hiring of domestic workers in 9 countries. Free Malaysia Today. Retrieved from https://

www.freemalaysiatoday.com/

category/nation/2017/10/27/

ngo-lauds-direct-hiring-of-

domestic-workers-from-9-

countries/.

Adilah, A. (2017, November 30). 300 Cambodian maids to arrive in March 2018. Malay Mail Online. Retrieved from https:// www.malaymail.com/news/ malaysia/2017/11/30/300cambodian-maids-to-arrive-inmarch-2018/1521609.

AEC (ASEAN Economic Community). (2015). ASEAN Economic Community Blueprint 2025. Retrieved from https://asean.org/? static_post=asean-economiccommunity-blueprint-2025.

Agreement Signed to Protect Migrant Workers. (2016, May 30). Khmer Times. Retrieved from https:// www.khmertimeskh.com/24334/ agreement-signed-to-protectmigrant-workers/.

ASEAN (Association of Southeast Asian Nations). (1999). The Bangkok Declaration on Irregular Migration. Retrieved from https:// www.iom.int/jahia/webdav/site/ myjahiasite/shared/shared/ mainsite/policy_and_research/ rcp/APC/
BANGKOK_DECLARATION.pdf.

ASEAN (Association of Southeast Asian Nations). (2012). ASEAN Agreement on the Movement of Natural Persons (MNP). Retrieved from http://investasean.asean.org/ files/upload/ASEAN\%20MNP\% 20Main\%20Text.pdf.

ASEAN (Association of Southeast Asian Nations). (2015). Kuala Lumpur Declaration on Irregular Movement of Persons in Southeast Asia. Retrieved from https:// asean.org/wp-content/ uploads/2012/05/Adopted-Kuala -Lumpur-Declaration-onIrregular-Movement-of-Personsin-Southeast-Asia.pdf .

Babulal, V, Karim. A, \& Arif, L. (2018, November 28). M'sia to sign MoU on Labour Supply with 3 countries. New Straits Times. Retrieved from https://www.nst.com.my/news/ nation/2018/11/435292/msiasign-mou-labour-supply-3countries.

Battistella, G. (2002). Unauthorized migrants as global workers in the ASEAN region. Southeast Asian Studies, 40(3).

Barker, A. (2018, February 24). Indonesian maid's death in Malaysia exposes 'brutal' human trafficking of migrant workers. ABC News. Retrieved from https:// www.abc.net.au/news/2018-0223/indonesian-womans-deathexposes-trafficking-of-migrantworkers/9476934

Best to Revert to Old System. (2018, July 29). Star Online. Retrieved from https://www.thestar.com.my/ news/nation/2018/07/29/best- 
to-revert-to-old-system-we-wantto-go-back-to-g2g-on-hiringforeign-workers-says-kula/ \#5JFdFXEi62ZBuEYm.99.

Cambodia urges Malaysia to expedite anti -human trafficking agreement. (2020, January 14). Free Malaysia Today. Retrieved from https:// www.freemalaysiatoday.com/ category/nation/2020/01/14/ cambodia-urges-malaysia-toexpedite-anti-human-traffickingagreement/.

Caram Asia et al. (2019, May 30). M’sia, Bangladesh must strictly regulate worker recruitment process. $\mathrm{Ma}$ laysia Kini. Retrieved from https://www.malaysiakini.com/ letters/477952.

Carvalho, M. (2016, February 10). 1.5 Million More to Come. Star Online. Retrieved from https:// www.thestar.com.my/news/ nation/2016/02/10/15-millionmore-to-come/.

Cheng, N. (2014, December 23). 494 illegals deported to Indonesia. Star Online. Retrieved from https:// www.thestar.com.my/news/ nation/2014/12/23/indonesianillegal-immigrants-deported/.

David, S. (2020, January 14). Ministry urges Malaysia to speed up maid protection agreement. Khmer Times. Retrieved from https:// www.khmertimeskh.com/5067940 5/ministry-urges-malaysia-to-speed -up-maid-protection-agreement.

DGICM (ASEAN Directors-General of Immigration Departments and Heads of Consular Affairs). (2014). Joint Press Statement of the 18th DGICM, 2-3 September 2014, Bandar
Seri Begawan, Brunei Darussalam. Retrieved from https:// www.asean.org/storage/images/ Statement/2014/Sept/Joint\% 20Press $\% 20$ Statement $\% 20$ of $\%$ 20the $\% 2018$ th $\% 20$ Meeting\% 20of\%20the $\% 20$ ASEAN\% 20Directors-General\%20of\% 20Immigration\%20Department\% 20 and $\% 20$ Heads $\% 20$ of $\%$ 20Consular\%20Affairs $\%$ 20Divisions $\% 20$ of $\% 20$ the $\%$ 20Ministries\%20of\%20Foreign $\%$ 20Affairs $\% 2018$ th\%20DGICM\% $20 \% 20 \% 20 \% 20$.pdf .

Dixit, K. (2019, September 15). Nepal and Malaysia rewrite rules for migrant labour. Nepali Times. Retrieved from https://www.nepalitimes.com/here -now/nepal-and-malaysia-rewriterules-for-migrant-labour/.

Govt working on improved, standardised MOU on hiring foreign workers. (2018, November 28). New Straits Times. Retrieved from https:// www.nst.com.my/news / nation/2018/11/435432/govtworking-improved-standardisedmou-hiring-foreign-workers.

Govt signs MoU on workers' rights with Cambodia. (2015, December 11). Star Online. Retrieved from https:// www.thestar.com.my/news/ nation/2015/12/11/govt-signsmou-on-workers-rights-withcambodia/ \#fMmBehmD55Sluydr.99.

Hall, A. (2019, July 17). Ethical recruitment dilemma. Star Online. Retrieved from https:// www.thestar.com.my/opinion/ letters/2019/07/17/ethicalrecruitment-dilemma/ \#jcxcAQFWpk7mFoG0.99 
Available Online at https://journal.unismuh.ac.id/index.php/otoritas

Otoritas : Jurnal Ilmu Pemerintahan, 10 (2), October 2020, 160

ILO (International Labour Organisation). (2016). Review of Labour Migration Policy in Malaysia: Tripartite Action to Enhance the Contribution of Labour Migration to Growth and Development in ASEAN. Bangkok: ILO Regional Office for Asia and the Pacific. Retrieved from http:// apmigration.ilo.org/resources/ review-of-labour-migrationpolicy-in-malaysia/at_download/ file1.

ILO (International Labour Organisation). (2018). Situation and gap analysis on Malaysian legislation, policies and programmes, and the ILO Forced Labour Convention and Protocol. Retrieved from https:// www.ilo.org/wcmsp5/groups/ public/---asia/---ro-bangkok/ documents/genericdocument/ wcms_650658.pdf.

Indonesia mulls ban on sending maids to Malaysia after abuse case. (2018, February 17). Straits Times. Retrieved from https:// www.straitstimes.com/asia/seasia/indonesia-mulls-ban-onsending-maids-to-malaysia-afterabuse-case.

Kannan, H. K. (2017a, May 25). Cambodia lifts ban on sending domestic workers here; maids to arrive soon. New Straits Times. Retrieved from https:// www.nst.com.my/news/ nation/2017/05/242580/ cambodia-lifts-ban-sendingdomestic-workers-here-maidsarrive-soon.

Kannan, H. K. (2017b, December 29). From Jan 1, it will take only eight days to hire a foreign maid. New Straits Times. Retrieved from https://www.nst.com.my/news/ nation/2017/12/319544/jan-1-it -will-take-only-eight-days-hireforeign-maid.

Khazanah Research Institute. (2018). The State of Household 2018: Different Realities. Retrieved from http:// www.krinstitute.org/assets/ contentMS/img/template/ editor/ FullReport_KRI_SOH_2018.pdf.

Kneebone, S. (2010). The governance of labor migration in Southeast Asia. Global Governance: A Review of Multilateralism and International Organizations, 16(3).

Kunthear, M. (2018, December 6). Migrant worker protection MoU signed. Khmer Times. Retrieved from https:// www.khmertimeskh.com/55647 4/migrant-worker-protectionmou-signed-2/

Lavenex, S., et. al. (2016). Regional migration governance. In T. A. Börzel and T. Risse (Eds.), The Oxford handbook of comparative regionalism. Oxford: Oxford University Press.

Lee, E. \& Idris, A. N. (2018, September 6). Overhauling The billion-ringgit migrant worker industry. The Edge Markets. Retrieved from https:// www.theedgemarkets.com/ article/cover-story-overhaulingbillionringgit-migrant-workerindustry.

Liow, J. C. Y. (2003). Malaysia's illegal Indonesian migrant labour problem: in search of solutions. Contemporary Southeast Asia, 25(1). 
Lokman, T., \& Fong, F. (2018, March 1). No Maids for you if you have a record. New Straits Times. Retrieved from https:// www.nst.com.my/news/ exclusive/2018/03/340084/nomaids-you-if-you-have-record.

Low, C. C., \& Mokhtar, K. S. (2017). Deportation Turn in Malaysia: Expansion, discourse and practice. Journal of Population and Social Studies, 25(2).

Malaysia looking at zero-cost system for recruitment of Bangladeshi workers, says Kulasegaran. (2020, January 7). Malay Mail Online. Retrieved from https:// www.malaymail.com/news/ malaysia/2020/01/07/malaysialooking-at-zero-cost-system-forrecruitment-of-bangladeshiworkers/1825606.

Malaysia's meeting with Indonesia to discuss maid ban postponed. (2018, February 20). Straits Times. Retrieved from https:// www.straitstimes.com/asia/seasia/malaysias-ambassador-tomeet-indonesian-minister-afterjakartas-proposed-maid-ban.

Malaysia targets middlemen to end debt bondage of migrant workers. (2018, December 23). Star Online. Retrieved from https:// www.thestar.com.my/news/ world/2018/12/23/malaysiatargets-middlemen-to-end-debtbondage-of-migrant-workers / \#UCpVwXIVQCSk4gqt.99.

Malaysia to go slow on labour MoU. (2018, November 29). Star Online. Retrieved from https:// www.thestar.com.my/news/ nation/2018/11/29/msia-to-go- slow-on-labour-mou-kula-wehave-to-resolve-issue-of-illegalforeign-workers-before-signin.

Malaysia wants to work with Bangladesh to repatriate illegal immigrants says Kula. (2018, September 26). Star Online. Retrieved from https://www.thestar.com.my/ news/nation/2018/09/26/ malaysia-wants-to-work-withbangladesh-to-repatriate-illegalimmigrants-says-kula/ \#4wdP4RyOVm3dAtzK.99.

Mandal, C. K. (2018, October 29). Nepal and Malaysia sign labour pact. Kathmandu Post. Retrieved from https://kathmandupost.com/ miscellaneous/2018/10/29/ nepal-malaysia-sign-labour-pact.

Marbun, J. (2014, December 22). Five hercules planes to repatriate illegal Indonesian workers form Malaysia. Republika. Retrieved from https://www.republika.co.id/ berita/breaking-news/ nasional/11/03/07/en/ international/14/12/22/ngzrf5five-hercules-planes-to-repatriate -illegal-indonesian-workers-formmalaysia.

Martin, P., \& Abella, M. (2014). Reaping the economic and social benefits of labour mobility: ASEAN 2015. Bangkok: ILO.

Migrant Forum in Asia. (2017). Government-to-Government Recruitment Benefits \& Drawbacks: Open Working Group on Labour Migration \& Recruitment Policy Brief \#3. Retrieved from http:// mfasia.org/migrantforumasia/wp -content/uploads/2017/01/3Policy-Brief-Human-Rights-inG2G-Agreements.pdf. 
Mohd A. M. H. (2018, September 30). Independent committee on foreign workers to start work in two weeks. New Straits Times. Retrieved from https:// www.nst.com.my/news/ nation/2018/09/416460/ independent-committee-foreignworkers-start-work-two-weeks.

Nepal courts cleared Malaysian firms; declared shut down as unlawful. (2019, February 19). New Malaysia Times. Retrieved from https:// newmalaysi-

atimes.com/2019/02/19/nepalcourts-cleared-malaysian-firmsdeclared-shut-down-as-unlawful/.

Nepal ready to negotiate MOU on labour cooperation with Malaysia. (2018, August 2). New Straits Times. Retrieved from https:// www.nst.com.my/news/ nation/2018/08/397163/nepalready-negotiate-mou-labourcooperation-malaysia.

Nesadurai, H. E. (2013). Malaysia's conflict with the Philippines and Indonesia over labour migration: economic security, interdependence and conflict trajectories. The Pacific Review, 26(1).

Nyan, L. A. (2016a, July 13). Migrant workers detained in Malaysia return home. Myammar Times. Retrieved from https:// www.mmtimes.com/nationalnews/21352-migrant-workersdetained-in-malaysia-returnhome.html.

Nyan, L. A. (2016b, August 9). Government begins repatriating $2000 \mathrm{mi}-$ grants from Malaysia. Myammar Times. Retrieved from https:// www.mmtimes.com/national- news/21833-government-beginsrepatriating-2000-migrants-frommalaysia.html.

Orbeta, A. \& Gonzales, K. G. (2013). Managing International Labor Migration in ASEAN: Themes from a SixCountry Study. PIDS Discussion Paper Series, No. 2013-26, Philippine Institute for Development Studies (PIDS), Makati City..

Palma, P. (2015, August 9). Govt Initiative Made to Fail? Daily Star. Retrieved from http:// www.thedailystar.net/frontpage/ govt-initiative-made-fail-124021.

Perumal, E. (2018, July 28). Foreign Workers: Nepal slams the door, unhappy with company monopoly. Star Online. Retrieved from https://www.thestar.com.my/ news/nation/2018/07/28/nomore-nepalese-workers-for-msiaembassy-discrepancies-inrecruitment-process-pushed-ourgovt-to-st.

Peter, Z. (2017, July 27). NGOs Help Six More Workers to Repatriate From Malaysia. Cambodia Daily. Retrieved from https:// www.cambodiadaily.com/news/ ngos-help-six-more-workers-torepatriate-from-malaysia132923/.

Poudal, U. (2018, October 30). Nepal, Malaysia Ink Labour Supply MoU. Himalayan Times. Retrieved from https://thehimalayantimes.com/ nepal/nepal-malaysia-ink-laboursupply-mou/, accessed January 30, 2019.

Purwaningsih, A. (2011, July 7). MoU not enough to protect Indonesian maids. Deutsche Welle. Retrieved 
Available Online at https://journal.unismuh.ac.id/index.php/otoritas

Otoritas : Jurnal Ilmu Pemerintahan, 10 (2), October 2020, 163

from https://www.dw.com/en/ mou-not-enough-to-protectindonesian-maids/a-6543145.

Rahim, R. (2019, December 12). Malaysia adopts fair practices in hiring Nepalese. Star Online. Retrieved from https:// www.thestar.com.my/news/ nation/2019/12/12/malaysiaadopts-fair-practices-in-hiringnepalese\#cxrecs_s.

Ramasamy, P. (2004). International Migration and Conflict: Foreign Labour in Malaysia. In A. Ananta \& E. N. Arifin (Eds.), International Migration in Southeast Asia. Singapore: Institute of Southeast Asian Studies.

Ramji-Nogales, J. (2017). Under the Canopy: Migration Governance in Southeast Asia. UCLA Journal of International Law and Foreign Affairs, 21(10).

Recruitment in Malaysia: Bangladesh won't send workers unless cost is cut, says minister. (2020, January 6). Star Online. Retrieved from https:// www.thestar.com.my/news/ regional/2020/01/06/ recruitment-in-malaysiabangladesh-wont-send-workersunless-cost-is-cut-says-minister.

Regional Support Office of the Bali Process (2012a). Overview of the Regional Support Office. Retrieved from https:// www.baliprocess.net/UserFiles/ baliprocess/File/V2\% 20Information\%20Sheet_RSO\% 20Feb\%2018(2).pdf.

Regional Support Office of the Bali Process (2012b). Bali Process Con- clusions on the Establishment of the RSO. Retrieved from https:// www.baliprocess.net/UserFiles/ baliprocess/File/RSO\% 20Information $\% 20$ Sheet $\% 20-\%$ 20Bali\%20Process\% 20Conclusions.pdf.

Rother, S. (2018). ASEAN Forum on Migrant Labour: A space for civil society in migration governance at the regional level?. Asia Pacific Viewpoint, 59(1).

Sabah deports 400 Filipino illegals. (2016, November 17). Straits Times. Retrieved from https:// www.straitstimes.com/asia/seasia/sabah-deports-400-filipinoillegals.

Sapkota, R., \& Alhadjri, Alyaa. (2018, July 20). Kleptocrats of Kathmandu and Kuala Lumpur. Nepali Times. Retrieved from https:// www.nepalitimes.com/banner/ kleptocrats-of-kathmandu-andkualalampur/.

Shah, A. (2015, December 10). Cambodian workers and maids to make comeback. News Straits Times. Retrieved from https:// www.nst.com.my/ news/2015/12/116670/ cambodian-workers-and-maidsmake-comeback.

Shah, A. (2017, December 4). Labour rights groups stunned by Malaysia-Cambodia agreement to protect domestic maids. News Straits Times. Retrieved from https:// www.nst.com.my/news/ nation/2017/12/310428/labour -rights-groups-stunned-malaysia -cambodia-agreement-protectdomestic. 
Available Online at https://journal.unismuh.ac.id/index.php/otoritas

Otoritas : Jurnal Ilmu Pemerintahan, 10 (2), October 2020, 164

Shahar, F. (2015, 10 December). 1,500 illegals repatriated via low-cost airlines. New Straits Times.

Sotheary, P. (2017, 4 October). Embassy brings workers home from Malaysia. Khmer Times.

Tay, C. (2019, October 8). Malaysia has 1.99 million foreign workers registered as at Aug 31. Edge Markets.

Thomas, J. (2020, January 7). Kula agrees with more transparent system for Bangladeshi workers. Free Malaysia Today.

Thuzar, M. (2018, April 23). Asean 2018: More work to be done on labour migration. Straits Times. Retrieved from https:// www.straitstimes.com/opinion/ asean-2018-more-work-to-bedone-on-labour-migration.

Tusher, H. J. (2016, February 9). 15 Lakh to Get Job in 3 Years. Daily Star. Retrieved from http:// www.thedailystar.net/ frontpage/15-lakh-get-job-3years-214810.

Voon, M. P. (2019, July 11). Agreement on new hiring system for Bangladesh workers by next month. Malaysia Kini. Retrieved from https://www.malaysiakini.com/ news/483442.

Wickramasekara, P. (2015). Bilateral agreements and memoranda of understanding on migration of low skilled workers: a review. Geneva: ILO.

World Bank. (2013). Immigration in Ma- laysia: Assessment of its Economic Effects and a Review of the Policy and System. Report Completed in Collaboration with ILMIA, Ministry of Human Resources of Malaysia. Retrieved from http:// psu.um.edu.my/images/psu/ doc/Recommended\%20Reading/ Immigration $\% 20 \mathrm{in} \%$ 20Malaysia.pdf.

World Bank. (2015). Malaysia Economic Monitor: Immigrant Labour. Washington, D.C.: World Bank Group.

Zainal, F. (2019, March 12). Better welfare for foreign workers. Star Online. Retrieved from https:// www.thestar.com.my/news / nation/2019/03/12/betterwelfare-for-foreign-workersemployers-laud-abolishment-ofoutsourcing-outfits-managingforei.

Zainul, E. (2018, October 25). No more middlemen in hiring of foreign workers next year. Edge Markets.

Zaw, Z. H. (2016, May 19). Embassy in Malaysia plans repatriations. Myammar Times. Retrieved from https://www.mmtimes.com/ national-news/20386-embassyin-malaysia-plansrepatriations.html

Zulfakar, M., \& Singh, D. (2020, May 19). Indonesia expected to lift maid ban in two months. Star Online. Retrieved from https:// www.thestar.com.my/news/ nation/2010/05/19/indonesiaexpected-to-lift-maid-ban-in-two -months 